\section{Relationship between frost hardiness of adults and seedlings of different tree species}

\author{
Maria Hofmann ${ }^{(1)}$, Michael Jager ${ }^{(1)}$, Helge Bruelheide ${ }^{(1-2)}$
}

The aim of this study was to investigate the relationship between frost hardiness and the macroclimatic niche of adult individuals and seedlings of eight temperate tree species. Frost damage was investigated on winter buds and needles of adult individuals and on freshly germinated seedlings. We hypothesized that frost hardiness of adult individuals and seedlings is in accordance with their macroclimatic niche and that frost hardiness of seedlings increases with increasing plant age. Frost hardiness was tested in a climate chamber by exposing the plant material to different freezing temperatures and was assessed by $\mathrm{LT}_{50}$-values. In contrast to our expectations, we did not find any relationship between $\mathrm{LT}_{50}$-values and the macroclimatic niche variables, neither for adults nor for seedlings. There was a positive trend between seedlings development and frost hardiness, although average frost hardiness of all species differed only between -7.5 and $-9{ }^{\circ} \mathrm{C}$ for one-week old and two- or four weeks old seedlings, respectively. We have to conclude that frost hardiness of adult individuals as well as seedlings at our study site does not reflect the species' geographic distribution range, and therefore, it seems not be possible to predict the geographical distribution ranges of tree species from their frost tolerance.

\section{Keywords: Developmental Stage, Electrolyte Leakage, $\mathrm{LT}_{50}$, Spring Frost}

\section{Introduction}

Out of all factors worldwide that potentially limit geographical distribution ranges of plants, minimum temperatures are considered the most important (Woodward 1987, Dahl 1998, Holten 1998). In particular, frost is thought to be the cause of northern and eastern distribution range boundaries of plant species in Europe (Sakai \& Larcher 1987 Pither 2003, Kreyling 2010). The coincidence between species distribution boundaries and freezing temperature thresholds has been already demonstrated for various plant species (Sakai \& Larcher 1987, Huntley 1990, Woodward 1997). For example, Fagus sylvatica $\mathrm{L}$. does not occur in regions with a mean temperature in January below $-3{ }^{\circ} \mathrm{C}$ (Bolte et al. 2007). However, these observations are purely based on correlations and knowledge on which plant organs are affected by frost in which phenological state is virtually absent. Low temperatures affect individuals directly or indirectly by frost dehydration (Pearce 2001, Beck et al. 2004), whereby single cells up to the whole organism can be damaged (Weiser 1970, Pearce 2001). Thus, tree species in the northern hemisphere have evolved a certain frost hardiness despite the high energetic costs involved (Huner et al. 1998). Frost hardiness of European plant species shows a seasonal pattern and at the end of the growing season it is induced by decreasing temperatures (Xin \& Browse 2000, Repo et al. 2001, Beck et al. 2004) and is brought about by accumulation of carbohydrates and dehydration of the cells, tissues and organs (Siminovitch \& Briggs 1953, Sakai \& Larcher 1987,

$\square$ (1) Institute of Biology / Geobotany and Botanical Garden, Martin Luther University Halle Wittenberg, Am Kirchtor 1, D-06108 Halle (Saale, Germany); (2) German Centre for Integrative Biodiversity Research (iDiv) Halle-Leipzig-Jena, Deutscher Platz 5e, D-04103 Leipzig (Germany)

@ Maria Hofmann (maria.hofmann@botanik.uni-halle.de)

Received: Jul 17, 2013 - Accepted: Feb 25, 2014

Citation: Hofmann M, Jager M, Bruelheide H, 2014. Relationship between frost hardiness of adults and seedlings of different tree species. iForest 7: 282-288 [online 2014-04-01] URL: http: //www.sisef.it/iforest/contents/?id=ifor1076-007

Communicated by: Elena Paoletti

Améglio et al. 2004, Thomas et al. 2004, Morin et al. 2007, Callister et al. 2008).

Long-lived plant species go through various development stages with different environmental condition requirements. It is wellknown that frost hardiness varies along the plant life cycle (Sakai \& Larcher 1987, Bigras et al. 2004, Taschler et al. 2004), with seedlings exhibiting a lower frost hardiness than adults. For example, Morin et al. (2007) showed for different European Quercus species that adults were significantly more frosttolerant than seedlings. However, despite such differences in frost tolerance between adults and juveniles, one would expect that frost tolerance mechanisms of different ontogenetic stages are similar for a given species. Moreover, seedlings and adults might not share the same micro-environment but are exposed to the same macro-climate at any growth location. In consequence, the survival and growth of seedlings of the tree species Acer pictum subsp. mono (Maximowicz) H. Ohashi and Fagus crenata Blume were found to be in accordance with the distribution patterns of the adult individuals of these species in Japan (Masaki et al. 2005).

Periods of low temperatures are critical events in the development of tree seedlings. While seeds of temperate tree species are generally frost-tolerant down to $-196{ }^{\circ} \mathrm{C}$ (Sakai $\&$ Larcher 1987), they lose frost hardiness with the onset of germination (Marcante et al. 2012). As most temperate and boreal tree species germinate at the beginning of the growing season in spring, they are often exposed to late frost events which frequently occur in the temperate and boreal zone (Bigras et al. 2004), and therefore, frost events can severely affect seedling growth and survival (Bigras et al. 2004, Kreyling et al. 2012). For plant species in an alpine glacier foreland, Marcante et al. (2012) showed that freezing temperatures in the growing season are potentially severe enough to kill plants at early stages of their development. Similarly, Funkenberg et al. (2012) demonstrated the importance of late frosts for establishment of Fallopia japonica (Houtt.) Ronse Decr. seedlings in Germany, whereby the freezing sensitivity depended on the timing, intensity and duration of late frost events. The fact that trees often can be grown in Botanical Gardens outside the species' native distribution range when planted as saplings, indicates that tree species distribution ranges might depend more on the susceptibility of seedlings rather than that of adults. Furthermore, frost hardiness of seedlings depends on their developmental stage. There is evidence that frost tolerance decreases with increasing seedling age as demonstrated by Bigras et al. (2004) for seedlings of Picea glauca (Moench) Voss.

In this study, we asked to which degree 

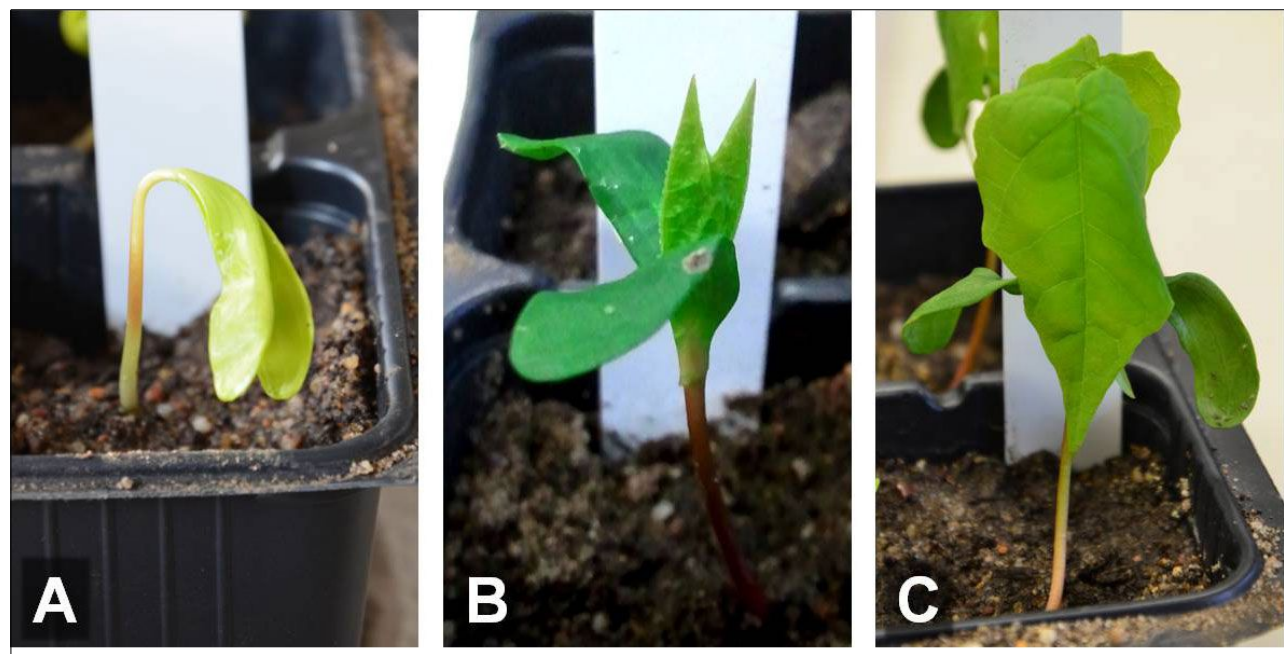

Fig. 1 - Developmental stages of oneweek (A, D), two-weeks (B, E) and four-weeks old seedlings $(\mathrm{C}, \mathrm{F})$ of Acer platanoides (A-C) and Pseudotsuga menziesii (D-F).
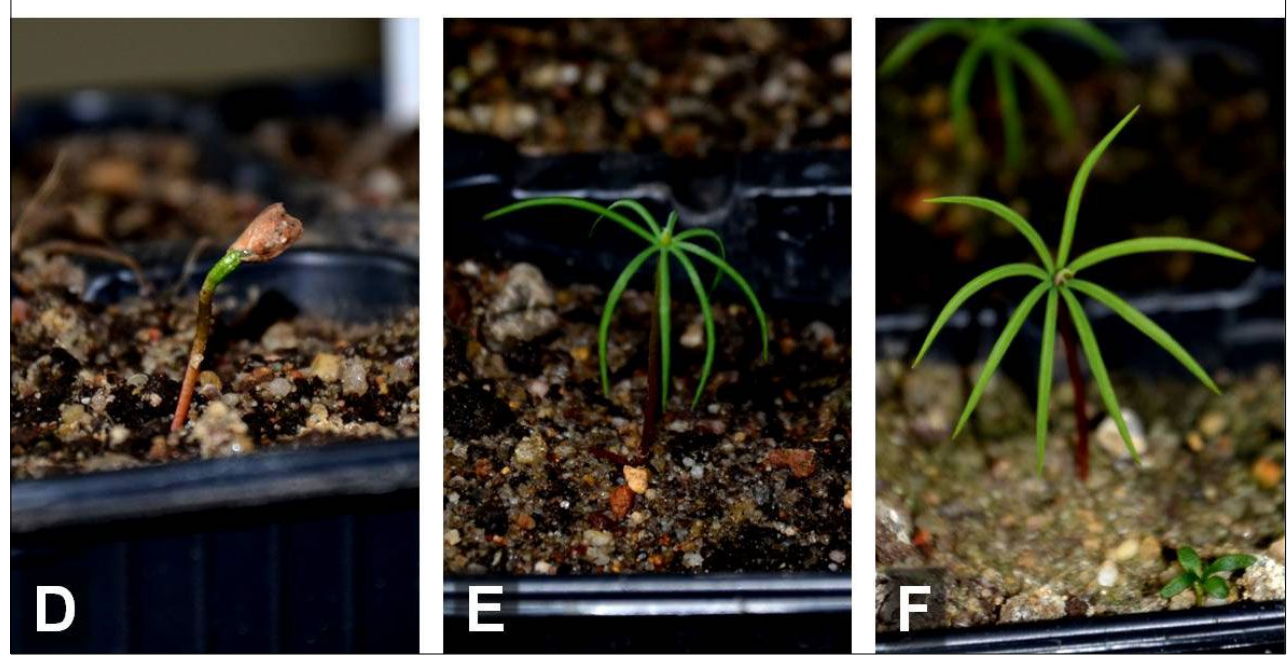

frost tolerance of adult individuals and seedlings of eight temperate tree species common to Central Europe corresponds to their geographical distribution range. We tested the hypothesis that the more tolerant to frost is a species the further its distribution range extends to regions with low winter temperatures.

In particular, we expected the species' geographical distribution is better explained by the frost tolerance of seedlings than that of adult individuals. Furthermore, we tested the hypothesis that the frost hardiness of seedlings increases with increasing developmental stage.

\section{Materials and Methods}

\section{Experimental design}

We investigated individuals of the following eight tree species: Acer negundo L., Acer platanoides L., Alnus glutinosa (L.) P. Gaertn., Betula pendula Roth, Fagus sylvatica L., Picea abies (L.) H. Karst., Pseudotsuga menziesii (Mirb.) Franco and Tilia cordata Mill. For all species we investigated four different development stages: adult trees, one-week, two-weeks and four-weeks old seedlings. While in the one-week old seedlings the first leaves (either the cotyledons or the primary leaves) were just unfolded, they were developed in two-weeks old seedlings and subsequent leaves already emerged in the four-week old seedlings (Fig. $1)$.

Frost hardiness of the adult individuals was analyzed on winter buds (A. negundo, $A$. platanoides, A. glutinosa, B. pendula, F. sylvatica and $T$. cordata) or needles ( $P$. abies and P. menziesii). Except for A. negundo, which is highly invasive in Central Germany, and P. menziesii, which is an important plantation species, all species were native to the study region in the surrounding of Halle (Saale), Germany (latitude: N $51.497^{\circ}$, longitude E $11.969^{\circ}$, elevation $87 \mathrm{~m}$ a.s.l., annual mean temp: $9.0^{\circ} \mathrm{C}$, annual precipitation: $490 \mathrm{~mm}$ ). Plant material was sampled about 12 hours before the start of the frost experiment and stored at $+4{ }^{\circ} \mathrm{C}$.

Frost hardiness of seedlings was analyzed on whole individuals. Seedlings derived from seeds collected from natural stands in Saxony-Anhalt (Landesdarre Saxony-Anhalt, Annaburg - Tab. 1). In early spring 2012 the seeds were sown in pots containing compost and sand $(2: 1 \mathrm{v} / \mathrm{v})$ in a glasshouse chamber (day/night cycle $12 \mathrm{~h}, 20{ }^{\circ} \mathrm{C} / 10^{\circ} \mathrm{C}$ ). Because of the low germination rates of $F$. sylvatica and $T$. cordata, further seedlings were collected in the field in April 2012. The seedlings of every development stage were acclimated in a climate chamber (RUMED, day/night cycle $12 \mathrm{~h}, 8{ }^{\circ} \mathrm{C} / 4{ }^{\circ} \mathrm{C} \pm 0.6{ }^{\circ} \mathrm{C}$ temperature, lamps from ISTA, $35000 \mathrm{Lu}$ men) one week prior to the frost experiment to simulate outdoor conditions.

\section{Frost experiment}

Frost hardiness was tested in a climate test chamber (SANYO Atmos Chamber MTH4400), using the procedure described in Hofmann et al. (2013). Frost hardiness of the adult species was determined in winter 2010/ 2011 (A. negundo, A. platanoides, A. glutinosa, F. sylvatica, T. cordata) and 2011/ 2012 (B. pendula, P. abies, P. menziesii), using one to seven individuals per species $(A$. negundo: $\mathrm{n}=6, A$. platanoides: $\mathrm{n}=5, A$. glutinosa: $\mathrm{n}=1, B$. pendula: $\mathrm{n}=1, F$. sylvatica: $\mathrm{n}=3, P$. abies: $\mathrm{n}=1, P$. menziesii: $\mathrm{n}$ $=1, T$. cordata $: \mathrm{n}=7$ ). Frost hardiness of the seedlings was determined in spring 2012. Briefly, the plant material was exposed step- 
wise to 11 temperature levels for buds of adult individuals: $+4{ }^{\circ} \mathrm{C},-4{ }^{\circ} \mathrm{C},-8{ }^{\circ} \mathrm{C},-12$ ${ }^{\circ} \mathrm{C},-16{ }^{\circ} \mathrm{C},-20{ }^{\circ} \mathrm{C},-24{ }^{\circ} \mathrm{C},-28{ }^{\circ} \mathrm{C},-32{ }^{\circ} \mathrm{C}$, $-40{ }^{\circ} \mathrm{C}$ and $-80{ }^{\circ} \mathrm{C}$; for seedlings: $+4{ }^{\circ} \mathrm{C}, 0$ ${ }^{\circ} \mathrm{C},-2{ }^{\circ} \mathrm{C},-4{ }^{\circ} \mathrm{C},-6{ }^{\circ} \mathrm{C},-8{ }^{\circ} \mathrm{C},-10{ }^{\circ} \mathrm{C},-14$ ${ }^{\circ} \mathrm{C},-18{ }^{\circ} \mathrm{C},-22{ }^{\circ} \mathrm{C}$ and $-40{ }^{\circ} \mathrm{C}$ with a cooling rate of 0.13 and $0.07{ }^{\circ} \mathrm{C} / \mathrm{min}$ between frost levels for adults and seedlings, respectively. Each temperature level lasted for 45 minutes (resulting in 8.15 hours in total). At the end of each level, one batch of winter buds from adult trees and eight pots with seedlings were removed from the climate test chamber and transferred to a refrigerator at $+4{ }^{\circ} \mathrm{C}$ to allow for controlled thawing and stored there until the next day. Eight replicates per treatment, resulting in a total of 88 replicates per developmental stage and species were considered.

\section{Assessment of frost hardiness of adult individuals}

Frost hardiness of the adult individuals was measured as the rate of electrolyte leakage of the buds. On the next day after frost exposure, buds were transferred into test tubes with 3\%-isopropanol solution and tested for electrolyte leakage according to Murray et al. (1989). Intracellular ice formation results in cell membrane disruption, whereby protoplasm escapes, resulting in an increase of the electrolyte conductivity in the surrounding solution (Ashworth \& Pearce 2002). The electrical conductivity in the solution was measured six times: first immediately after preparing the buds to define a baseline for electrical conductivity $\left(\mathrm{C}_{0}\right)$, followed by four measurements after $4 \mathrm{~h}, 24 \mathrm{~h}, 48 \mathrm{~h}$ and $72 \mathrm{~h}$ $\left(\mathrm{C}_{\mathrm{t}}\right)$ after the initial measurement. A final measurement was conducted after boiling the samples for 20 minutes $\left(\mathrm{C}_{\mathrm{b}}\right)$, which resulted in a complete destruction of the tissue and served as the maximum electrical conductivity of the plant material. Relative Conductivity $(R C)$ was calculated according to eqn. 1 (Murray et al. 1989):

$$
R C=\frac{C_{t}-C_{0}}{C_{b}-C_{0}}=1-e^{-k \cdot t}
$$

The rate of electrolyte leakage ( $k$-values) was calculated for all samples $(\mathrm{n}=88)$ per species and development stage, by a 4-parametric sigmoid regression according to eqn. 2:

$$
k=f(T)=c+\frac{a}{1+e^{-\left(\frac{T-L T_{50}}{b}\right)}}
$$

where $a$ is the range of $k$-values, $b$ is the steepness of the curve, $c$ is the minimum $k$ values, $T$ is the temperature. The regression parameter $L T_{50}$ describes the point of inflection of the resulting curve and indicates the temperature at which $50 \%$ of maximum electrolyte leakage was reached.

Tab. 1 - Geographic origin (in decimal degrees) of the seed material of the investigated species.

\begin{tabular}{lcc}
\hline Species & Latitude & Longitude \\
\hline Acer negundo & N 51.4970 & E 11.9688 \\
Acer platanoides & N 51.4970 & E 11.9688 \\
Alnus glutinosa & N 51.6833 & E 11.4667 \\
Betula pendula & N 52.4465 & E 11.4862 \\
Fagus sylvatica & N 51.4347 & E 12.0379 \\
Picea abies & N 51.6993 & E 10.7219 \\
Pseudotsuga menziesii & N 52.4325 & E 11.7698 \\
Tilia cordata & N 51.9411 & E 11.4281 \\
\hline
\end{tabular}

\section{Assessment of frost hardiness of seedlings}

Frost hardiness of the seedlings was measured by visual inspection of the seedlings' survival. On the following day of the frost experiment the seedlings were transferred into a glasshouse chamber (day/night cycle $12 \mathrm{~h}, 20^{\circ} \mathrm{C} / 10^{\circ} \mathrm{C}$ ). Two days later the survival of every individual seedling was assessed. Survival was then regressed on the temperature levels applied in a logistic model and $L T_{50}$ was obtained from eqn. 3 :

$$
\ln \left(\frac{p}{1-p}\right)=f(T)=a T+b
$$

where $p$ is the proportion of seedlings that survived, $a$ and $b$ are regression parameters, $T$ is the temperature.

The point of inflection of the above function is the $L T_{50}$, i.e., the temperature at which $50 \%$ of the seedlings survived, and is given as $-b / a$. A pre-study demonstrated that the $L T_{50}$-values obtained by electrolyte leakage were comparable to the $L T_{50}$-values calculated by survival rates. These results show that frost hardiness of seedlings assessed by visual inspection and electrolyte leakage was closely related (Fig. 2).

\section{Statistical analysis}

Frost hardiness of the different development stages described by the $L T_{50}$-values was related to the species macroclimatic niches. Therefore, Therefore, global occurrence data on the investigated species, based on floristic atlases and online published databases, were georeferenced and digitized using ArcMap (ESRI). Climatic data were extracted from the Worldclim dataset (Hijmans et al. 2005) in a 2.5 arc minutes grid across the whole distribution range. For the following analyses we used the lower $1^{\text {st }}$ percentile of all macroclimatic variables that described frost conditions (Tab. 2). To test the first hypothesis, i.e., the relationship between frost tolerance and the climatic conditions in winter, linear regression models were applied using $L T_{50}$-values and the minimum temperature of the coldest month, as well as the minimum temperatures of each months from November to May. As for the second hypothesis, differences between adults and seedlings and between different seedling ages were verified using paired $t$-tests. Additionally, we related the $L T_{50}$-values of the adult individuals to the $L T_{50}$-values of all three development stages of the seedlings, using linear regression models. Differences in seedlings frost tolerance among species was tested using a generalized linear model with binomial error distribution, including temperature level and species identity as fixed factors. These two-factorial models were subjected to Tukey's post-hoc tests to deter-

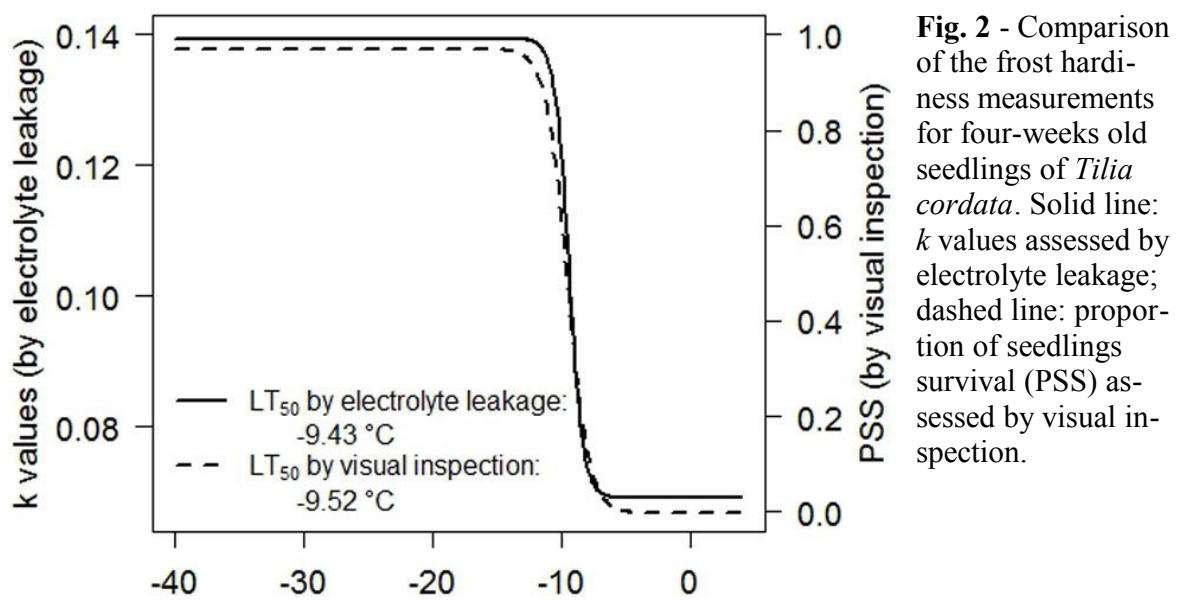

Temperature $\left[{ }^{\circ} \mathrm{C}\right]$ 
Tab. 2 - Minimum temperature of the coldest month (the lower 1 st percentile $-{ }^{\circ} \mathrm{C}$ ) and frost tolerance expressed as $L T_{50}$-values $\left({ }^{\circ} \mathrm{C}\right)$ of the seedlings (one-week, two-weeks and fourweeks old) and the adult individuals for all the eight species studied. Different letters in the seedlings columns indicate statistically significant differences between species according to Tukey's post-hoc tests.

\begin{tabular}{|c|c|c|c|c|c|}
\hline \multirow{2}{*}{ Species } & \multirow{2}{*}{$\begin{array}{l}\text { Min temp } \\
\text { coldest } \\
\text { month }\end{array}$} & \multicolumn{3}{|c|}{ Seedlings } & \multirow{2}{*}{$\begin{array}{c}\text { Adult } \\
\text { individual }\end{array}$} \\
\hline & & One-week & Two-weeks & Four-weeks & \\
\hline Acer negundo & -26.4 & $-6.26^{a b}$ & $-9.11^{b c}$ & $-9.35^{a}$ & -32.17 \\
\hline Acer platanoides & -21.1 & $-8.32^{a b c}$ & $-9.39^{\mathrm{cd}}$ & $-9.35^{\text {a }}$ & -32.56 \\
\hline Alnus glutinosa & -22 & $-6.01^{a}$ & $-6.76^{a}$ & $-8.28^{a}$ & -22.55 \\
\hline Betula pendula & -21.8 & $-6.26^{a b}$ & $-8.83^{a b c}$ & $-7.77^{a}$ & -23.41 \\
\hline Fagus sylvatica & -10.2 & $-8.59 b c$ & $-9.39^{\mathrm{cd}}$ & $-9.63^{\text {a }}$ & -32.18 \\
\hline Picea abies & -21.1 & $-10.04^{c}$ & $-10.69^{\mathrm{cd}}$ & $-9.35^{a}$ & -29.2 \\
\hline Pseudotsuga menziesii & -20 & $-9.42^{c}$ & $-12.08^{\mathrm{d}}$ & $-9.54^{a}$ & -36.61 \\
\hline Tilia cordata & -23.9 & $-6.01^{a}$ & $-7.52^{a b}$ & $-9.93^{a}$ & -45.29 \\
\hline
\end{tabular}

Tab. 3 - Summary of $\mathrm{R}^{2}$ and p-values of the linear regression models tested for relationships between $L T_{50}$-values of the buds of adult individuals and the macroclimatic variables as drawn from the Worldclim dataset. For all regressions, degrees of freedom $=6$.

\begin{tabular}{lcc}
\hline \multirow{2}{*}{ Variable } & \multicolumn{2}{c}{ Adult individuals } \\
\cline { 2 - 3 } & $\mathbf{R}^{\mathbf{2}}$ & p-value \\
\hline Min. temp. coldest month & 0.145 & 0.353 \\
Min. temp. in November & 0.152 & 0.34 \\
Min. temp. in December & 0.146 & 0.35 \\
Min. temp. in January & 0.146 & 0.351 \\
Min. temp. in February & 0.158 & 0.33 \\
\hline
\end{tabular}

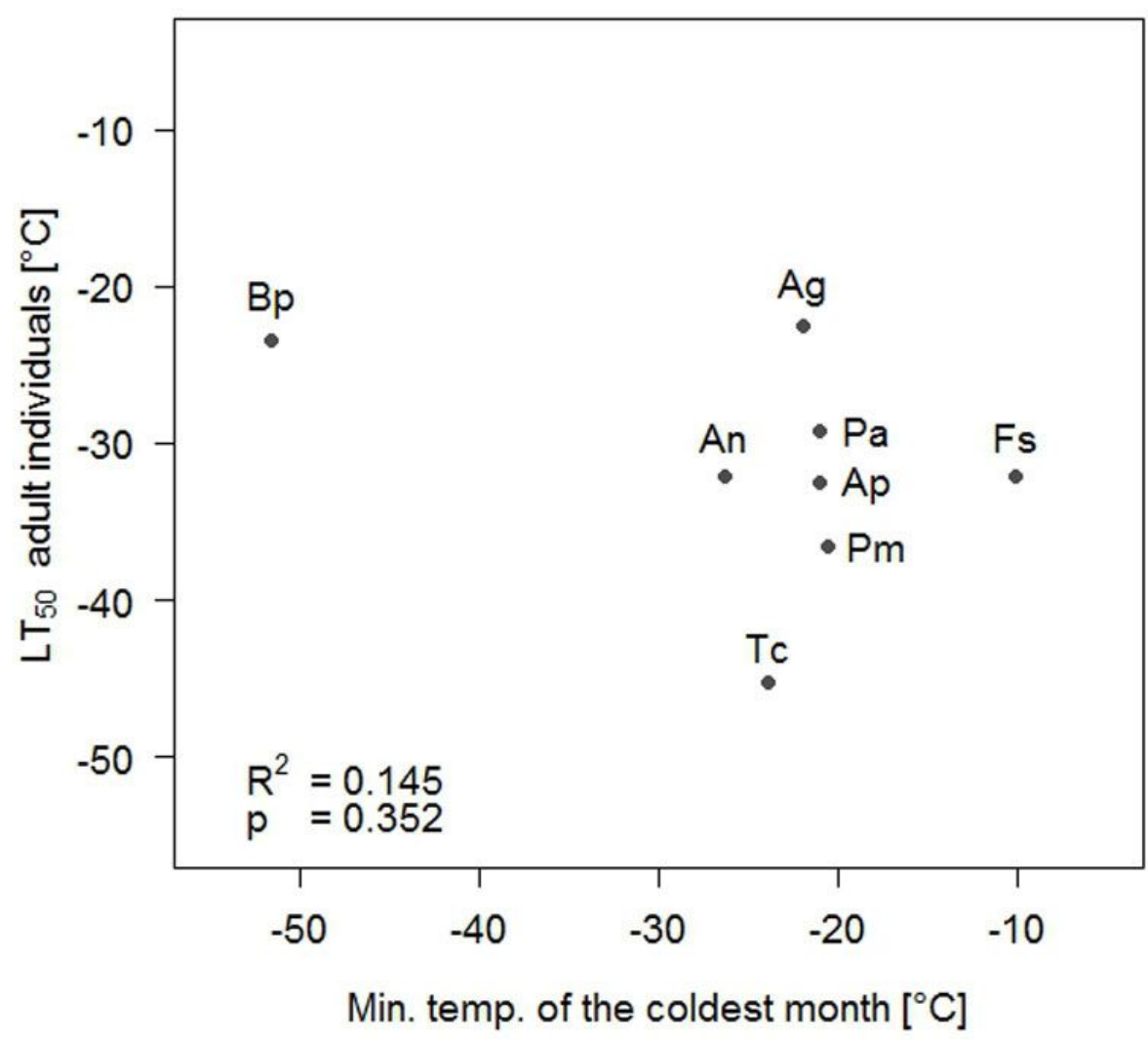

Fig. 3 - Correlation between frost hardiness of adult individuals expressed as $L T_{50}$-values and minimum temperature of the coldest month. (Ag): Alnus glutinosa; (An): Acer negundo; (Ap): Acer platanoides; (Bp): Betula pendula; (Fs): Fagus sylvatica; (Pa): Picea abies; (Pm): Pseudotsuga menziesii; (Tc): Tilia cordata. mine which species differed from each other. Similarly, we tested for differences in frost tolerance among the different seedlings development stages, using the temperature level and the seedling age as fixed factors.

The sigmoid regressions were calculated with Sigmaplot 11.0 (Systat Software ${ }^{\circledR}$, v. 2008), whereas all the other statistical analyses were carried out using the software package R version 2.12.0 (R Development Core Team 2010).

\section{Results}

Frost hardiness of the adult individuals, expressed as $L T_{50}$-values, ranged from -45.29 (T. cordata) to $-22.55{ }^{\circ} \mathrm{C}(A$. glutinosa Tab. 2). No significant relationships were found between the $L T_{50}$ value of the adult individuals and any of the macroclimatic variables tested (Tab. 3, Fig. 3). Moreover, no significant correlations were detected between the frost hardiness of seedlings and any climatic variable (Tab. 4). There was one marginally significant effect between frost hardiness of four-weeks-old seedlings and the minimum temperature of April, but the direction of the effect was opposite to the expectation, with the tendency of species with lower frost hardiness of seedlings to occur at the higher minimum temperature. In addition, no significant correlations were found between the frost hardiness of any development stage of the seedlings and the frost hardiness of the adult individuals (Fig. 4).

Frost hardiness of the seedlings ranged from -12.08 to $-6.01{ }^{\circ} \mathrm{C}$, whereby $A$. glutinosa and $T$. cordata exhibited the lowest frost hardiness (one-week old seedlings) and $P$. menziesii (two-weeks old seedlings) showed the highest (Tab. 2). Species only differed in the age class of one-week and twoweeks old seedlings, while there was no statistically significant difference in frost tolerance among species in four-weeks old seedlings. One-week and four-week old seedlings of $T$. cordata and A. glutinosa were significantly more sensitive to frost than those of $F$. sylvatica, $P$. abies and $P$. menziesii (Tab. 2). Across all species, frost hardiness of seedlings was significantly lower than that of adults ( $p<0.001$ for adults versus one-, twoand four-weeks old seedlings after paired $t$ tests). While frost tolerance across all species differed between one- and twoweeks old seedlings $(p=0.0028)$, there was no difference between two- and four-weeks old seedlings $(\mathrm{p}=0.883)$, according to paired $t$-tests.

Seedlings of $A$. negundo, A. platanoides, $A$. glutinosa, $F$. sylvatica and $T$. cordata showed an increase in frost hardiness with increasing age with a maximal difference of $3.9^{\circ} \mathrm{C}$ between the one-week-old and the four-weeks-old developmental stage (T. cordata - Tab. 2). In contrast, the seedlings of B. pendula, P. abies and P. menziesii had the 
highest frost hardiness at the two-weeks-old developmental stage.

\section{Discussion}

We found no relationship between the fros tolerance of the eight tree species and the macroclimatic variables derived from their geographical distribution range, neither for adult adults winter buds or needles, nor for seedlings at three different ages. Thus, the hypothesis of a relationship between species' frost hardiness and the extension of their distribution range to regions with low winter temperatures (our first hypothesis) has to be rejected. As this result is exactly the opposite of the current biogeographical understanding, we have to consider that there might be several methodological reasons. A major drawback of the approach adopted in this study was that all plant material subjected to frost hardiness measurements was taken from the same geographical location, i.e., Halle (Saale). This may preclude the possibility of detecting any effects of intra-specific adaptation. Indeed, it might be that the study species were adapted to the much more moderate frost conditions at the study site than to those encountered at the geographical distribution limits, where the climatic variables considered had been drawn from. Even the lowest measured frost hardiness of any adult tree (i.e., A. glutinosa with a frost hardiness of $-22.6{ }^{\circ} \mathrm{C}$ ) was high enough to safely survive under the climatic winter conditions in the study region. Many studies has investigated local adaptation to frost, demonstrating a relationship between frost hardiness and the climatic conditions of the populations' geographic origins, with species from northern provenances or higher elevation being more frost tolerant than species from southern provenances or lower elevation (Beuker et al. 1998, Jensen \& Deans 2004, Aldrete et al. 2008, Kathke \& Bruelheide 2011, Kreyling et al. 2012). In particular, species with a wide distribution

Tab. 4 - Summary of $\mathrm{R}^{2}$ and p-values of the linear regression models tested for relationships between $L T_{50}$-values of all three development stages of the seedlings (one-week, two-weeks and four-weeks old), as obtained from the 4-parametric sigmoid regression, and $L T_{50}$-values of the adult individuals, as well as the macroclimatic variables (from the Worldclim dataset). For all regressions, degrees of freedom $=6$.

\begin{tabular}{lcccccc}
\hline \multirow{2}{*}{ Variable } & \multicolumn{2}{c}{ One-week } & \multicolumn{2}{c}{ Two-weeks } & \multicolumn{2}{c}{ Four-weeks } \\
\cline { 2 - 7 } & $\mathbf{R}^{\mathbf{2}}$ & $\mathbf{p}-$-value & $\mathbf{R}^{\mathbf{2}}$ & $\mathbf{p}$-value & $\mathbf{R}^{\mathbf{2}}$ & p-value \\
\hline$L T_{50}$ adult individals & $<0.001$ & 0.946 & 0.029 & 0.685 & 0.27 & 0.2 \\
Min. temp. in March & 0.07 & 0.528 & 0.002 & 0.909 & 0.478 & 0.057 \\
Min. temp. in April & 0.001 & 0.929 & 0.034 & 0.664 & 0.491 & 0.053 \\
Min. temp. in May & 0.015 & 0.772 & 0.177 & 0.299 & 0.458 & 0.065 \\
\hline
\end{tabular}

range such as Quercus robur L. have developed ecotypes with respect to frost hardiness (Deans \& Harvey 1996). However, if intraspecific adaptation had blurred inter-specific differences in frost tolerance between species, this would indicate that intra-specific variation in frost hardiness might be higher than variation among species growing in the same area. Testing this assumption would require to take samples of both adults and seedlings from different climatic zones for different species. Preferably, the different provenances would also include the range boundaries of the different species. For adult trees, there are not only logistic obstacles with such a sampling scheme, as simultaneous sampling from different regions involves the risk to include plants with a different degree of acclimatization. It is well known that winter frost hardiness is acquired gradually and the degree of hardening depends on outdoor temperatures (Sakai \& Larcher 1987, Beck et al. 2004). While we could control for differences in the degree of hardening by taking all bud and needle samples of adult trees at the time of maximum hardening, this will probably not be possible when sampling over a large geographical area. A solution to this challenge would be provenance trials of different tree species grown under the same common garden conditions. For seedlings, simultaneous testing of provenances is sim- pler as the seeds can be germinated at the same time.

Our study is not the only one that failed to detect differences in frost tolerance between different species. Comparing eight congeneric pairs of grassland species with contrasting distribution ranges, Hofmann et al. (2013) also failed to confirm the correspondence between frost resistance and macroclimatic niche variables. Similar to our results, Baltzer et al. (2007) detected no relationship between the fundamental and realized niches with respect to the seasonality of the rainfall for different tropical tree species.

In contrast to our expectation, seedlings frost tolerance did not reflect the species' macroclimatic niche better than that of adults. Since long, frost hardiness of seedlings has been claimed to be an important limiting factor of the distribution ranges of tree species. This statement is mainly based on cursory observations on lethal effects of exceptional frost events on seedlings, as reported by Szafer (1932) for $F$. sylvatica. Our results did reveal only moderate differences in frost hardiness of seedlings of the different species studied. Thus, seedlings of different tree species would be affected quite similarly by exceptional late frost events. As a consequence, seedling frost hardiness can hardly be a good predictor for the different distribution ranges of tree species. Similar
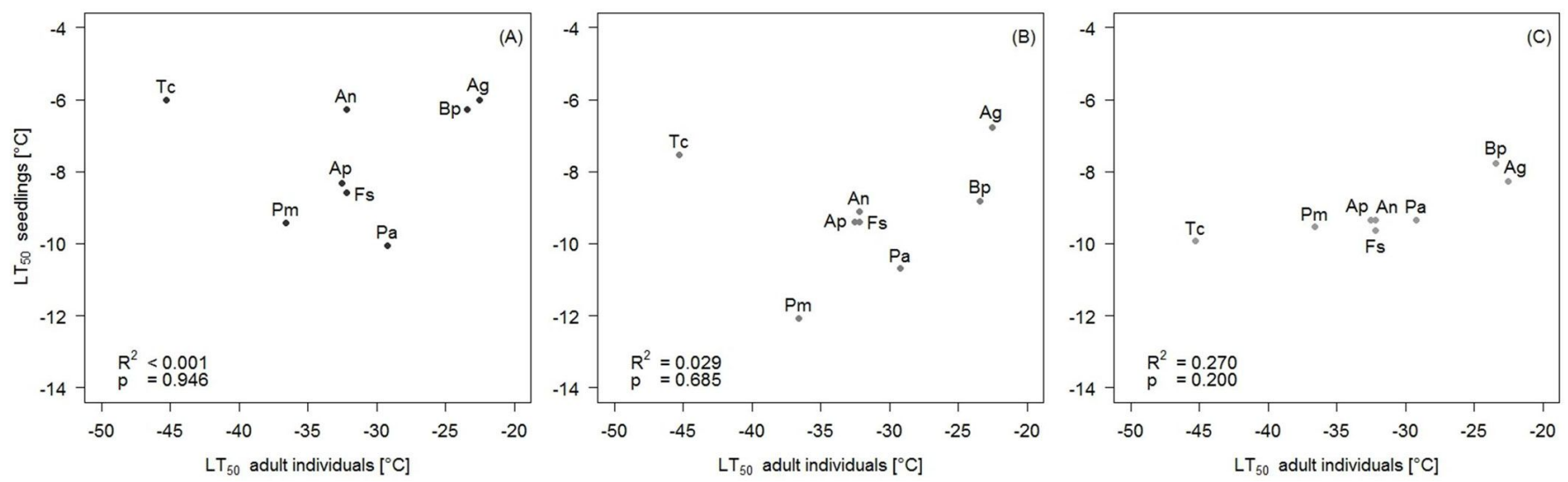

Fig. 4 - Frost hardiness of one-week (A), two-weeks (B) as well as four-weeks old seedlings (C) and frost hardiness of the adult individuals expressed as $L T_{50}$-values. (Ag): Alnus glutinosa; (An) Acer negundo; (Ap): Acer platanoides; (Bp): Betula pendula; (Fs): Fagus sylvatica; (Pa): Picea abies; $(\mathrm{Pm})$ : Pseudotsuga menziesii; $(\mathrm{Tc})$ : Tilia cordata. 
doubts on the relevance of late frost events have also been expressed by other authors, such as by Funkenberg et al. (2012) for the establishment of $F$. japonica seedlings.

It has to be considered that our study focused only on seedling frost lethality and not on the effects of non-lethal freezing temperatures on seedling performance. It is possible, that non-lethal freezing temperatures higher than the measured $L T_{50}$-values result in a weakening of plants, making them more vulnerable to subsequent frost events or to other types of biotic or abiotic stress (Repo et al 2008). For example, these non-lethal effects led to a reduced growth of $Q$. robur $\mathrm{L}$. seedlings and the ensuing growth reduction has been interpreted as a limiting factor for the northern distribution boundary of this species (Repo et al. 2008). Similarly, comparing the growing rates of $F$. sylvatica seedlings, Kreyling et al. (2012) reported a reduced growth as a consequence of spring frost events in the Bulgarian but not in the German provenance. Non-lethal freezing temperatures also resulted in reduced growth and survival of Digitalis purpurea L. seedlings at the altitudinal distribution limit (Bruelheide \& Heinemeyer 2002).

We found support for our second hypothesis as the investigated seedlings showed increasing frost hardiness with increasing age for five of eight species. With the exception of the two evergreen species, $P$. abies and $P$. menziesii, the four-weeks old seedling were more frost tolerant than the one-week old seedlings. This might point to fundamental differences in the sensitivity of cotyledons and primary leaves between angiosperm and gymnosperm seedlings. While cotyledons seem to be more susceptible to frosts than primary leaves in angiosperms, while the opposite might be the case for gymnosperms. However, organ-specific tests would be required to test this hypothesis.

As frost events become rarer with the progress of the growing season and frost hardiness of our six angiosperm seedlings increases with seedling age, the risk of being damaged by late frost events in spring decreases disproportionally with time. This underlines the role of the germination timing. A later germination has been often interpreted as acclimation to late frost events. For example, Chuine \& Cour (1999) postulated that the timing of germination is adaptive to climate conditions of the species' geographical distribution range. Our results show that this might not be the case, as frost hardiness of one-week old seedlings of different species is rather similar, which has the consequence that early germinating tree species take higher risks, irrespective of their macroclimatic niche.

\section{Conclusion}

Based on our experimental results, predic- tions on the geographical distribution range of the eight species considered based on their frost tolerance seems to be unfeasible. Thus, the general assumption that minimum temperatures below a species-specific threshold simply kill needles, buds or seedlings has to be reconsidered. Nevertheless, frost might operate through a multitude of other mechanisms, affecting organs different from needles or buds, or biotic interactions such as pollination, thus contributing to limit the distribution ranges of European tree species.

\section{Acknowledgments}

We thank C. Voigt for the useful comments on seedlings cultivation and G. Seidler for the help with compiling the distribution data and maps. This study was financially supported by the graduate scholarship of Saxony- Anhalt.

\section{References}

Aldrete A, Mexal JG, Burr KE (2008). Seedling cold hardiness, bud set, and bud break in nine provenances of Pinus greggii Engelm. Forest Ecology and Management 255: 3672-3676. doi: 10.1016/j.foreco.2008.02.054

Améglio T, Decourteix M, Alves G, Valentin V, Sakr S, Julien J, Petel G, Guilliot A, Lacointe A (2004). Temperature effects on xylem sap osmolarity in walnut trees: evidence for a vitalistic model of winter embolism repair. Tree Physiology 24: 785-793. - doi: 10.1093/treephys/24.7. 785

Ashworth E, Pearce R (2002). Extracellular freezing in leaves of freezing-sensitive species. Planta 214: 798-805. - doi: 10.1007/s00425-0010683-3

Baltzer JL, Davies SJ, Noor NSM, Kassim AR, LaFrankie JV (2007). Geographical distributions in tropical trees: can geographical range predict performance and habitat association in co-occurring tree species? Journal of Biogeography 34: 1916-1926. - doi: 10.1111/j.1365-2699.2007.01 739. $\mathrm{x}$

Beck E, Heim R, Hansen J (2004). Plant resistance to cold stress: mechanisms and environmental signals triggering frost hardening and dehardening. Journal of Biosciences 29: 449-459. doi: 10.1007/BF02712118

Beuker E, Valtonen E, Repo T (1998). Seasonal variation in the frost hardiness of Scots pine and Norway spruce in old provenance experiments in Finland. Forest Ecology and Management 107: 87-98. - doi: 10.1016/S0378-1127(97)00344-7

Bigras FJ, Coursolle C, Margolis HA (2004). Survival and growth of Picea glauca seedlings as a function of freezing temperatures and exposure times during budbreak and shoot elongation. Scandinavian Journal of Forest Research 19: 206-216. [online] URL: http://www.ingentaconnect.com/content/tandf/sfor/2004/00000019/000 00003/art00002

Bolte A, Czajkowski T, Kompa T (2007). The north-eastern distribution range of European beech: a review. Forestry 80: 413-429. - doi: 10.1093/forestry/cpm028

Bruelheide H, Heinemeyer A (2002). Climatic factors controlling the eastern and altitudinal distribution boundary of Digitalis purpurea L. in Germany. Flora 197: 475-490. - doi: 10.1078/ 0367-2530-00064

Callister AN, Arndt SK, Ades PK, Merchant A, Rowell D, Adams MA (2008). Leaf osmotic potential of Eucalyptus hybrids responds differently to freezing and drought, with little clonal variation. Tree Physiology 28: 1297-1304. - doi: 10.1093/treephys/28.8.1297

Chuine I, Cour P (1999). Climatic determinants of budburst seasonality in four temperate-zone tree species. New Phytologist 143: 339-349. - doi: 10.1046/j.1469-8137.1999.00445.x

Dahl E (1998). The phytogeography of northern Europe (British Isles, Fennoscandia and adjacent areas). Cambridge University Press, Cambridge, UK, pp. 297. - doi: 10.1017/CBO97805115651 82

Deans JD, Harvey FJ (1996). Frost hardiness of 16 European provenances of sessile oak growing in Scotland. Forestry 69: 5-11. - doi: 10.1093/fore stry/69.1.5

Funkenberg T, Roderus D, Buhk C (2012). Effects of climatic factors on Fallopia japonica s.l. seedling establishment: evidence from laboratory experiments. Plant Species Biology 27: 218-225. - doi: 10.1111/j.1442-1984.2011.00349.x

Hijmans RJ, Cameron SE, Parra JL, Jones PG, Jarvis A (2005). Very high resolution interpolated climate surfaces for global land areas. International Journal of Climatology 25: 1965-1978. doi: $10.1002 /$ joc. 1276

Hofmann M, Buetof A, Welk E, Bruelheide H (2013). Relationship between fundamental and realized niche with respect to frost and drought resistance. Preslia 85: 1-17.

Holten JI (1998). Vertical distribution patterns of vascular plants in the Fennoscandian mountain range. Ecologie 29: 129-138. [online] URL: http://cat.inist.fr/?aModele $=$ afficheN\&cpsidt $=24$ 29239

Huner NPA, Öquist G, Sarhan F (1998). Energy balance and acclimation to light and cold. Trends in Plant Science 3: 224-230. - doi: 10.1016/S1360-1385(98)01248-5

Huntley B (1990). European post-glacial forests: compositional changes in response to climatic change. Journal of Vegetation Science 1: 507518. - doi: $10.2307 / 3235785$

Jensen JS, Deans JD (2004). Late autumn frost resistance of twelve North European provenances of Quercus species. Scandinavian Journal of Forest Research 19: 390-399. - doi: 10.1080/ 02827580410019391

Kathke S, Bruelheide H (2011). Differences in frost hardiness of two Norway spruce morphotypes growing at Mt. Brocken, Germany. Flora 206: 120-126. - doi: 10.1016/j.flora.2010.09.007 Kreyling J (2010). Winter climate change: a critical factor for temperate vegetation performance. Ecology 91: 1939-1948. - doi: 10.1890/09-11 60.1

Kreyling J, Thiel D, Nagy L, Jentsch A, Huber G, 
Konnert M, Beierkuhnlein C (2012). Late frost sensitivity of juvenile Fagus sylvatica L. differs between southern Germany and Bulgaria and depends on preceding air temperature. European Journal of Forest Research 131: 717-725. - doi: 10.1007/s10342-011-0544-y

Marcante S, Sierra-Almeida A, Spindelböck JP, Erschbamer B, Neuner G (2012). Frost as a limiting factor for recruitment and establishment of early development stages in an alpine glacier foreland? Journal of Vegetation Science 23: 858868. - doi: 10.1111/j.1654-1103.2012.01411.x Masaki T, Osumi K, Takahashi K, Hozshizaki K (2005). Seedling dynamics of Acer mono and Fagus crenata: an environmental filter limiting their adult distributions. Plant Ecology 177: 189199. - doi: 10.1007/s11258-005-2177-z

Morin X, Améglio T, Ahas R, Kurz-Besson C, Lanta V, Lebourgeois F, Miglietta F, Chuine I (2007). Variation in cold hardiness and carbohydrate concentration from dormancy induction to bud burst among provenances of three European oak species. Tree Physiology 27: 817-825. - doi: 10.1093/treephys/27.6.817

Murray MB, Cape JN, Fowler D (1989). Quantification of frost damage in plant tissues by rates of electrolyte leakage. New Phytologist 113: 307 311. - doi: 10.1111/j.1469-8137.1989.tb024 $08 \mathrm{x}$

Pearce RS (2001). Plant freezing and damage. An- nals of Botany 87: 417-424. - doi: 10.1006/anbo. 2000.1352

Pither J (2003). Climate tolerance and interspecific variation in geographic range size. Proceedings of the Royal Society of London 270: 475481. - doi: 10.1098/rspb.2002.2275

R Development Core Team (2010). R: a language and environment for statistical computing. $\mathrm{R}$ Foundation for Statistical Computing, Vienna, Austria. [online] URL: http://www.r-project.org/ Repo T, Nilsson JE, Rikala R, Ryyppö A, Sutinen ML (2001). Cold hardiness of scots pine (Pinus sylvestris L.). In: "Conifer cold hardiness". Kluwer Academic Publishers, Dordrecht, The Netherlands, pp. 463-493.

Repo T, Mononen K, Alvila L, Pakkanen TT, Hänninen H (2008). Cold acclimation of pedunculate oak (Quercus robur L.) at its northernmost distribution range. Environmental and Experimental Botany 63: 59-70. - doi: 10.1016/j. envexpbot.2007.10.023

Sakai A, Larcher W (1987). Frost survival of plants. Springer, Berlin, Germany, pp. 321. - doi: 10.1007/978-3-642-71745-1

Siminovitch D, Briggs DR (1953). Studies on the chemistry of the living bark of the black locust in relation to its frost hardiness. III. The validity of plasmolysis and desiccation tests for determining the frost hardiness of bark tissue. Plant Physiology 28: 15-34. - doi: 10.1104/pp.28.1.15
Szafer W (1932). The beech and the beech forests in Poland. Veröffentlichung des Geobotanischen Instituts der Stiftung Rübel in Zürich 8: 169-181. Taschler D, Beikircher B, Neuner G (2004). Frost resistance and ice nucleation in leaves of five woody timberline species measured in situ during shoot expansion. Tree Physiology 24: 331337. - doi: 10.1093/treephys/24.3.331

Thomas CD, Cameron A, Green RE, Bakkenes M, Beaumont LJ, Collingham YC, Erasmus BFN, de Siqueira MF, Grainger A, Hannah L, Hughes L, Huntley B, van Jaarsveld AS, Midgley GF, Miles L, Ortega-Huerta MA, Peterson AT, Phillips OL, Williams SE (2004). Extinction risk from climate change. Nature 427: 145-148. - doi: 10.1038 /nature 02121

Weiser CJ (1970). Cold resistance and injury in woody plants. Science 169: 1269-1278. - doi: 10.1126/science.169.3952.1269

Woodward FI (1987). Climate and plant distribution. Cambridge University Press, Cambridge, UK, pp.174.

Woodward FI (1997). Life at the edge: a 14-year study of a Verbena officinalis population's interactions with climate. Journal of Ecology 85: 899906. - doi: 10.2307/2960610

Xin Z, Browse J (2000). Cold comfort farm: the acclimation of plants to freezing temperatures. Plant, Cell and Environment 23: 893-902. - doi: 10.1046/j.1365-3040.2000.00611.x 